\title{
Salmonella spp. Implication in Products of Wastewater Irrigation
}

Amina Abubakari*

Department of Laboratory Technology, Faculty of Health Sciences, Kumasi Technical University, Kumasi, Ghana

${ }^{*}$ Corresponding author: Amina Abubakari, Department of Laboratory Technology, Faculty of Health Sciences, Kumasi Technical University, Kumasi- Ghana, Tel: +233-264-250-658; E-mail: aminaabubakari@yahoo.com

Received date: August 07, 2018; Accepted date: September 24, 2018; Published date: October 3, 2018

Copyright: @ 2018 Abubakari A. This is an open-access article distributed under the terms of the Creative Commons Attribution License; which permits unrestricted use; distribution; and reproduction in any medium; provided the original author and source are credited.

\begin{abstract}
This study was conducted to assess the occurrence of Salmonella spp. in lettuce (Lactucasativa), manured soil and wastewater. An initial analysis was carried out for indicator organisms such as E. coli and Total coliforms to be able to ascertain their presence prior to assessment of pathogenic microorganism. The study was carried out in Kumasi the second largest city in Ghana. A total of 111 samples were aseptically collected and analysed for Salmonella spp. using standard microbiological laboratory protocols. Out of 111 samples, 6(5.4\%), 11(9.9\%) and $4(3.6 \%)$ showed positive for lettuce, manured soil and irrigation water respectively. When one way ANNOVA was used to analysed the data the mean positive values showed no significant difference among the 3 groups of samples analysed $(P=0.17)$. The study revealed that, wastewater which farmers rely on for unrestricted irrigation all year round, lettuce which is consumed raw and manured soil from irrigation fields are all contaminated with Salmonella spp.
\end{abstract}

Keywords: Salmonella spp.; Irrigation; Lettuce; Implication; Wastewater

\section{Introduction}

Salmonella spp. is one of the pathogenic bacterium which causes diarrhoea, fever, and abdominal cramps 12 to 72 hours after infection usually lasting 4 to 7 days. In some persons, the diarrhoea may be so severe and infection may sometimes spread from the intestines to the blood stream, and then to other body sites which could result in death. In Africa, over 30,000 children are reported to die every year due to the consumption of contaminated food [1]. Fresh fruits and vegetables are increasingly recognized as potential sources of diseases [2,3]. Vegetables that are eaten uncooked are among the products associated with food borne disease outbreaks in the Unites States [4]. The elderly, infants, and those with impaired immune systems are more likely to have a severe illness. Every year, approximately 42,000 cases of Salmonellosis are reported in the United States (CDC). Children are the most likely to get Salmonellosis and the rate of diagnosed infections in children less than five years old is higher than the rate in all other persons. Vegetables can become contaminated by pathogens while growing, during harvest, by post-harvest handling, or distribution. It is estimated that approximately 400 persons die each year with acute Salmonellosis (CDC). In some persons it can also result in pain in their joints, irritation of the eyes, and painful urination which could last for months or years, sometimes leading to chronic arthritis which is difficult to treat. Population growth, coupled with increasingly lack of water supply and sanitation give rise to large volumes of wastewater, which sometimes end up in our water bodies either partially treated or untreated.

Desperate farmers who do not get portable water for irrigation depend on this water source to irrigate their produce. Demand for fresh fruit and vegetables as well as provision of job opportunities and income for farmers and their family members is the driving force for this activity. Although this is good for both consumers and farmers and their families, the health risk associated with it is highly significant since wastewater irrigation has been implicated in most pathogenic disease outbreaks.

Microbiological quality of lettuce on three farms where wastewater is used in Kumasi were studied to determine the CFU levels of Total coliforms, faecal coliforms, Enterococci, E. coli and Salmonella using standard methods. Total coliforms on the lettuce varied from $4.93 \times$ $104 \mathrm{cfu}$ to $6.17 \times 104 \mathrm{cfu}$. Faecal coliforms ranged from $3.48 \times 103 \mathrm{cfu}$ to $4.66 \times 104 \mathrm{cfu}$ and E. coli $2.98 \times 103 \mathrm{cfu}$ to $3.86 \times 104 \mathrm{cfu}$. Salmonella and Enterococci levels ranged from $2.50 \times 102$ cfu to $2.72 \times$ $102 \mathrm{cfu}$ and $0.68 \times 10 \mathrm{cfu}$ to $2.05 \times 10 \mathrm{cfu}$ respectively. Studies have extensively looked at this particular area but in bit and pieces, not holistically on all the possible sources of contamination of the raw eaten vegetables by these organism and more so Salmonella which is pathogenic and pose serious health challenge to the public. Studies conducted in Kumasi by Keraita et al. [5] show that the microbiological contaminants in irrigation water sources in most cases exceed the WHO recommendation. According to Amoah et al. [6], poultry manure which most wastewater irrigation vegetable farmers use are sources of potential health risk.

\section{Objective of study}

- The broader objective was to assess Salmonella spp. implication in wastewater, lettuce (Lactucasativa) and manured soils on which vegetables are cultivated

- To achieve this broader objective, initial identification and quantification of Total coliforms and E. coli as indicator organisms in the same samples was carried out

\section{Materials and Methods}

\section{Study site and design}

The study was conducted in Kumasi, where an early survey was done, mapping out the wastewater irrigation sites. Kumasi is the capital 
of the Ashanti Region of Ghana where majority of the farmers engage in wastewater irrigation farming. Hand-held GPS was used in capturing the entire wastewater irrigation site within the study area which was subsequently superimposed on the goggle earth map to obtain clear locations of the study area showing all the farms and irrigation waters (Figure 1). During the initial survey farmers and their families working on the various irrigation farms numbered approximately 250 but one hundred and fifty (150) farmers agreed to be recruited and also allowed samples to be taken from their farms for this study. Kumasi is located between latitude $6^{\circ} 30$ and $7^{\circ} 00 \mathrm{~N}$ and longitude $1^{\circ} 30$ and $2^{\circ} 00 \mathrm{~W}$. It has a wet semi-equatorial climate with an annual rainfall of around $1400 \mathrm{~mm}$ with two distinct rainy seasons. The mean annual temperature is $25.7^{\circ} \mathrm{C}$ with a relative humidity ranging from $53 \%-93 \%$. Kumasi is the second largest city in Ghana and it is about $270 \mathrm{Km}$ north to the national capital, Accra. It has a growth rate of $5.4 \%$ with an average household size of 5.1 persons [7]. Majority of the areas in Kumasi were wastewater is used for irrigation lie in the South-Eastern.

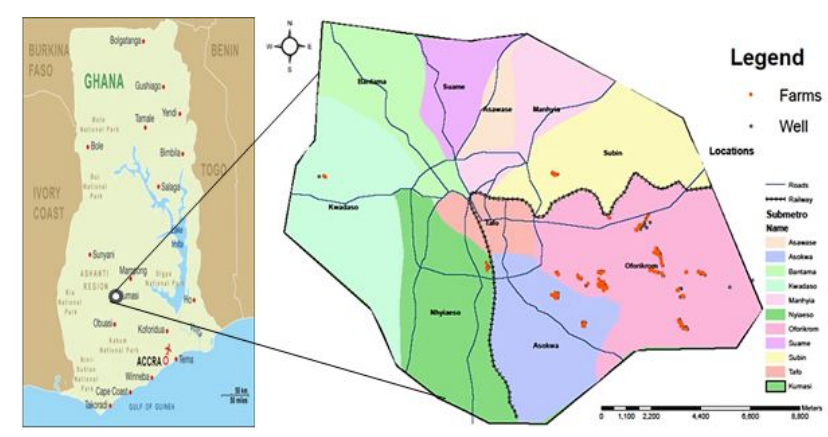

Figure 1: Kumasi an insert in Ghana map showing irrigation farms and impoundments for irrigation.

\section{Sampling procedure}

Three whole lettuce heads were aseptically picked from each bed with sterile Knives into sterile plastic bags (Stomacher ${ }^{(\mathrm{R})}$ lab system from Seward, UK) and sealed. From each bed, the lettuce heads were selected at random from the far ends and also in the middle to represent triplicate samples.

Manured Soil from beds were vegetables were sampled were taken in triplicates with sterile spatula into sterile plastic bags (Stomacher ${ }^{(R)}$ lab system) sealed and put into cooling boxes with cooling elements.

Wastewater used for irrigation was sampled into sterile pre-labelled $500 \mathrm{ml}$ bottles.

Samples were transported in cooling boxes containing cooling elements into the Microbiology Research laboratory for analysis within three hours.

\section{Laboratory analysis for Salmonella spp. in irrigation samples}

Lettuce were weighed and washed with distilled water $(1 \mathrm{~L})$ each. Serial dilutions of $10^{-1}-10^{-2}$ were made by taking $1 \mathrm{~m}$ of the sample added to $9 \mathrm{ml}$ of peptone water in test tubes and vortexed for thorough blending. It was then incubated at $37^{\circ} \mathrm{C}$ for $24 \mathrm{hrs}$. Tubes that showed growth by the presence of turbidity and gas were selected for another inoculation on selenite broth and incubated at $37^{\circ} \mathrm{C}$ for $24 \mathrm{hrs}$.
Positive samples were later inoculated onto Salmonella Shigella (SS) agar plates and incubated at $37^{\circ} \mathrm{C}$; suspected colonies were purified by sub culturing onto fresh plates. Typical Salmonella colonies which were colourless with black centers were inoculated on Triple Sugar Iron agar (TSI) slants and incubated at $37^{\circ} \mathrm{C}$ for $24 \mathrm{hrs}$.

Confirmation was done by using latex agglutination kit for Salmonella (Salmonella polyvalent 'O'group A-Z antiserum agglutination test kit).

One gram (1g) wet weight of manured soil was added to $9 \mathrm{ml}$ of peptone water, incubated at $37^{\circ} \mathrm{C}$ for $18-24 \mathrm{hrs}$. Tubes which showed growth were inoculated into $9 \mathrm{ml}$ of selenite broth and incubated again at $37^{\circ} \mathrm{C}$ for $18-24 \mathrm{hrs}$.

Positive tubes with turbid appearance were transferred onto Salmonella Shigella (SS) agar plates, incubated of $37^{\circ} \mathrm{C}$ for $18-24 \mathrm{hrs}$. Plates showing colonies of colourless with black centers were purified.

First confirmation was done by using TSI slants and then salmonella polyvalent 'O' group A-Z antiserum latex kit.

A serial dilution of $10^{-1}-10^{-2}$ was prepared by pipetting $1 \mathrm{ml}$ of the wastewater sample into $9 \mathrm{ml}$ of peptone water and incubated at $37^{\circ} \mathrm{C}$ for 18-2 $4 \mathrm{hrs}$. Turbid tubes were considered positive. Subsequent inoculation was done in tubes containing selenite broth and inoculated at $37^{\circ} \mathrm{C}$ for $18-24 \mathrm{hrs}$.

Positive tubes were selected and culturing done on Salmonella Shigella(SS) agar and incubated at $37^{\circ} \mathrm{C}$ for $18-24 \mathrm{hrs}$.

Salmonella colonies on the plates were identified morphologically as colourless colonies with black centers. Isolates were purified and then inoculated by stabbing TSI slants and stored at $37^{\circ} \mathrm{C}$ for $24 \mathrm{hrs}$ and observed for gas production and slant colour for confirmation.

Serological confirmation was also than using salmonella polyvalent ' $O$ ' group A-Z antiserum latex kit according to the instructions provided by the manufacturer.

A loop-full of the test organism's pure colony was added to one drop of Salmonella antisera distributed onto a reaction card. An even suspension was obtained by careful emulsification, after which the card was gently whirled.

The test organism was recorded positive for Salmonella spp. if agglutination occurred within 1-2 minutes. Salmonella spp. antiserum was substituted for normal saline as control for another typical reaction.

\section{Laboratory analysis for total coliforms and $E$. coli in lettuce, manured soil and wastewater}

Lettuce were weighed and homogenized with distilled water. 1 millitre of water samples were pipetted and a dilution of each made up to $10^{-1}-10^{-2}$ with $9 \mathrm{ml}$ of distilled water. The later diluent $\left(10^{-2}\right)$ was added to a beaker containing $90 \mathrm{ml}$ of distilled water mixed with one pack of colisure powder (Quanti-Tray/2000).

$10 \mathrm{~g}$ of dry manured soil sample was added to $90 \mathrm{ml}$ of distilled water in a beaker and mixed thoroughly. One sachet of colisure powder was poured into the sample mixture and allowed to mix well by shaken.

The mixture was allowed to stand for some time while shaking it in between to give room for thorough mixture. $1 \mathrm{ml}$ of the wastewater was pipetted into $9 \mathrm{ml}$ of distilled water and subsequent dilutions were 
made from the $10 \mathrm{ml}$ to a factor of $10^{-1}-10^{-2}$. The later diluent was poured into $90 \mathrm{ml}$ of distilled water. It was then poured into the quantitray and heat sealed. Incubation was done at $35^{\circ} \mathrm{C}$ for $18-24 \mathrm{hrs}$.

Readings for total coliforms and E. Coli was done by identifying yellow to red magenta wells indicating that, the coliforms have metabolize colisure's nutrient-indicator and when 6-watt, $365 \mathrm{~m}$, UV light in a dark room was passed through the surface of the sample the wells that fluoresce given purple colour were counted as containing $E$. coli colonies per $100 \mathrm{ml}$ of sample.

\section{Results}

A total of one hundred and eleven (111) each of lettuce, manured soil which supports the growth of wastewater irrigated produce and then wastewater used for irrigation (irrigation water) were aseptically collected and analysed. Result (Table 1) indicated Salmonella spp. presence in lettuce, manured soil and irrigation water as $6(5.4 \%)$, $11(9.9 \%)$ and $4(3.6 \%)$, respectively. Manured soil had the highest percentage of Salmonella spp. which may be due to the fact that most of the manures are from chicken containing high loads of Salmonella according to previous research and are poorly treated.

\begin{tabular}{|l|l|l|}
\hline Samples type $(\mathbf{n}=111)$ & $\begin{array}{l}\text { Salmonella spp. positive } \\
\text { result }\end{array}$ & $\begin{array}{l}\text { Percentage } \\
\text { positive }\end{array}$ \\
\hline Lettuce & 6 & 5.4 \\
\hline Manured soil* & 11 & 9.9 \\
\hline Irrigation water & 4 & 3.6 \\
\hline Total & 21 & 18.91 \\
\hline *Soil mixed with untreated poultry manure &
\end{tabular}

Table 1: Number of Samples indicated Salmonella spp. positive.

Apart from this study determining the presence of Salmonella spp./ in the samples, concentrations were also determined for both indicator organisms and Salmonella spp./ for both the wet and the dry seasons.

Result of this study indicated significant variations $(\mathrm{P}<0.05)$ in the mean log concentrations of all the microorganisms investigated in the wet and the dry seasons (Table 2).

For Salmonella spp., the mean log concentrations for the dry season was found to be within the WHO standard for unrestricted irrigation with the wet season been a little above the WHO standard.

Total coliforms and E. coli presented mean log concentrations between 3-4 logs higher than the acceptable standards for unrestricted irrigation in the dry and wet seasons (Table 2).

\begin{tabular}{|l|l|l|}
\hline Microorganism & Mean log cfu/100ml \pm SD & P-value \\
\hline Salmonella spp. & $2.524 \pm 0.984$ & 0.017 \\
\hline Dry season & $3.692 \pm 0.388$ & \\
\hline Wet Season & \multicolumn{2}{|l|}{} \\
\hline Total coliform & $7.557 \pm 0.201$ & 0 \\
\hline Dry season & $7.915 \pm 0.371$ & \\
\hline Wet Season &
\end{tabular}

\begin{tabular}{|l|l|l|}
\hline E. coli & \multicolumn{2}{|l|}{} \\
\hline Dry season & $6.619 \pm 0.260$ & 0 \\
\hline Wet Season & $7.488 \pm 0.356$ & \\
\hline SD $=$ Standard Deviation & \multicolumn{2}{|l|}{} \\
\hline
\end{tabular}

Table 2: Concentrations of Salmonella spp. in samples expressed in log $\mathrm{cfu} / 100 \mathrm{ml}$ of samples.

\section{Discussion}

Unrestricted agricultural practices with wastewater should be carefully monitored and planned and supported with hygiene protocols. This is to reduce un-necessary associated health risk especially in poor communities due to lack of strict policies on the use of wastewater. The World Health Organization [8] made recommendations for standard thresholds of $103 \mathrm{FC} / 100 \mathrm{ml}$ and $\leq 1$ egg/L of faecal coliform, respectively in wastewater used for unrestricted irrigation. Although manured soil application on farms by agricultural farmers provide nutrients to the vegetables, it introduces pathogens which poses health risk to man which requires serious attention [9]. A study in Zaria, Nigeria, showed that water sampled from households with livestock contains Salmonella spp. while water from households without livestock had no Salmonella spp. [10]. The difference is believed to be the introduction of the pathogens through animal husbandry operations such as the application of their faeces as organic manure without adequate treatment. The presence of Salmonella spp. in the products of this current study therefore agrees with the facts that, since most farmers within the study area apply untreated poultry manure it could highly be the source within urban and peri-urban $[11,12]$.

This study presented results with $E$. coli and Total coliforms concentrations in the samples to be high for both seasons with mean levels exceeding the $1 \times 10^{3} / 100 \mathrm{ml}$ recommended by WHO [13] for unrestricted irrigation. There were excesses of 3 to 4 logs in all seasons which could be attributed to the fact that about $90 \%$ of wastewater generated even in the capital cities of Ghana are not treated and eventually mixed up with storm drain which most farmers rely on for unrestricted irrigation [14]. The results also confirmed studies by Gupta et al. [15] which reported high concentrations of E. coli in vegetables irrigated with wastewater. Amoah et al. [16] also confirmed in their studies that, drains and streams highly contaminated with faecal coliform concentrations above the WHO acceptable level was the primary water source used in irrigation of most vegetables in Accra. On the seasonal effects, the dry samples had lower concentrations of $E$. coli and total coliform concentrations compared to those reported for the wet season which confirms the studies reported by Seidu et al. [17], which indicated in their study that, lettuce from wastewater irrigated farms had a six times chance of $E$. coli O157:H7 contamination during the wet season compared to the dry season which is similar to the observation from this current study. This study observed low concentrations of Salmonella spp. in all the samples for both seasons, agreeing with the WHO limits of within 3-4 logs [13]. Although they were present in low concentrations, Salmonella spp. and E. coli O157:H7 are reported as having low infectivity dose of 10-100 cells [18] which can result in a very huge health effect or outcomes. If this is the case then, unrestricted irrigation should be devoid of these pathogenic microorganisms and therefore the needed caution. Often reports indicate that fresh produce 
is responsible for about $22 \%$ of all food borne disease infections $[19,20]$. Report by Sivapalasingam et al. [4] indicates a strong link between lettuce and pathogenic organisms that can cause food borne illnesses. Their report further indicated that $29 \%$ (5 out of 17 ) of all lettuce-related outbreaks were linked to pathogenic microorganisms and $38 \%$ (five out of 13 ) of all these outbreaks with fresh produce were associated with lettuce. Their observation defers slightly from results obtained from this study which could be due to the high temperatures $\left(24.7^{\circ} \mathrm{C}-37.2^{\circ} \mathrm{C}\right)$ experienced during the study which could inhibit the growth of Salmonella spp.

Consumer's food safety depends on series of event beginning from the production fields or on-farm, market and finally to consumers for consumption with each of these events been essential. Estimates of contaminated food illnesses in developing countries presents a major challenge since infections are mostly treated at home and often not documented [21]. Studies have indicated that Salmonella spp. infect over 1.6 million humans within United States costing the nation about $\$ 15$ billion yearly [22]. Although this study also detected Salmonella spp. in wastewater, manured soil and more especially lettuce which is consumed raw, little is known in Ghana about the health cost implications of pathogenic organisms which needs to be given attention. Involvement of Salmonella spp. in these samples agrees with reports from studies indicating the presence of pathogenic microorganisms been generally transmitted directly via contaminated foods, water and crops $[23,24]$. The role of free-ranging birds and livestock in pathogen recirculation and local transmission has been noted on and around farms $[25,26]$ This is in line with this current study that has detected microbial pathogens in high levels in the manured soil of irrigation fields. The rather high levels of Total coliforms and $E$. coli in all the samples agree with a previous study conducted by Amoah et al. [27]. Again it is revealed that about 50-90\% of the vegetables consumed in the major cities in West Africa are produced from urban and peri-urban communities, where most of the irrigation water is polluted [28]. Since majority of the salad been prepared are obtained from the sources where this study took samples [29], policy makers should attach serious importance to it and enforce the existing policies on unrestricted irrigation practices. Again an observation from the study showed that farmers mostly used manure from livestock on their farms but these serve as pathogen reservoir and consequently serves as a channel for the transmission of pathogens which also agrees with a similar report by Oliveira et al. [30]. Faecal matter of grazing livestock was also frequently observed close to the irrigation areas. These eventually are washed into the nearby irrigation water during a rain fall event increasing contamination by pathogens greatly as also reported by Karesh et al. [31]. This current study has therefore shown that microbial contamination of vegetables especially those that are consumed raw may occur through contamination from the farm which could result from the quality of soil, and irrigation water [6]. Although poor post-harvest handling of in the market and during food preparation may also contribute to the contamination [26].

\section{Conclusion}

This study has revealed that, unrestricted vegetables from Kumasi has high concentrations of $E$. coli and Total coliforms with their mean levels exceeding $1 \times 10^{3} / 100 \mathrm{ml}$ which presents an excess of 3-4 logs of E.coli and Total coliforms beyond the World Health Organization recommendations. There are also some levels of pathogenic microorganism such as Salmonella spp. present in the water used for irrigation, manured soil and the vegetables produced under these conditions. These therefore predispose both farmers and consumers to infections due to accidental ingestion of manured soil and wastewater and the consumption of lettuce.

The conclusions from this study coupled with the fact that stake holders in the use of wastewater for irrigation and consumers of the produce lack basic knowledge in the area; more education is needed as well as enforcement of existing policies. More pragmatic and effective low cost irrigation technologies should also be promoted.

\section{Acknowledgement}

The author acknowledges the contribution of the Norwegian Research Council, Norway. The Department of Theoretical and Applied Biology, KNUST, Kumasi and finally, Department of Laboratory Technology, Faculty of Health Sciences, Kumasi Technical University, Kumasi-Ghana.

\section{References}

1. Mensah P, Yeboah-Manu D, Owusu-DarkoK, Ablordey A (2002) Street foods in Accra, Ghana: how safe are they? Bull World Health Organ 80: 546-554.

2. Beuchat LR (1998) Surface decontamination of fruits and vegetables eaten raw: A review: Food safety unit, World Health Organization, WHO/FSF/98.2.

3. Ibenyassine K, AitMhand R, Karamoko Y, Cohen N, Ennaji MM (2006) Use of repetitive DNA sequences to determine the persistence of enteropathogenic Escherichia coli in vegetables and in soil grown in fields treated with contaminated irrigation water. Lett Appl Microbiol 43: 528-533.

4. Sivapalasingam S, Friedman CR, Cohen L, Tauxe RV (2004) Fresh produce: A growing cause of outbreaks of foodborne illness in the United States, 1973 through 1997. J Food Prot 67: 2342-2353.

5. Keraita B, Drechsel P, Amoah P (2003) Influence of urban wastewater on stream water quality and agriculture in and around Kumasi, Ghana. Envir Urban 15: 171-178.

6. Amoah P, Drechsel P, Abaidoo C (2005) Irrigated urban vegetables production in Ghana: Sources of pathogen contamination and health risk elimination. Irrig Drain 54: 49-61.

7. Kumasi Metropolitan Assembly (KMA) Development Plan, (2006-2009). Report for Ministry of Local Government, Rural and Environment Development plan for KMA,( 2010-2013).

8. WHO (1989) Guidelines for the Safe Use of Wastewater in Agriculture, WHO, Geneva.

9. Yang QW, Shu WS, Qiu JW, Wang HB, Lan CY (2004) Lead in paddy soils and rice plants and its potential health risk around Lechang Lead/Zinc Mine, Guangdong, and China. Envir Int 30: 883-889.

10. Abakpa GO, Umoh VJ, Ameh JB (2011) Prevalence of Salmonella spp. in some environmental samples from some households engaged in livestock farming in some parts of Zaria, Nigeria. Continental J Microbiol 5: 6-11.

11. Orji UM, Onuigbo CH, Mbata IT (2005) Isolation of Salmonella from poultry droppings and other environmental sources in Awka, Nigeria. Int J Infec Dis 9: 86-89.

12. Rosewell A (2010) Soil-transmitted helminth infection and urbanization in 880 primary school children in Nicaragua, 2005. Trop Doct 40: 141-143.

13. WHO (2006) Guidelines for the Safe Use of Wastewater, Excreta and Greywater, Volume 2: Wastewater Use in Agriculture, World Health Organization, Geneva.

14. Scott CA, Faruqui NI, Raschid-Sally L (eds) (2004) Wastewater Use in Irrigated Agriculture: Confronting the Livelihood and Environmental Realities, CABI Publishing, Wallingford, UK, pp 113-125. 
Citation: Abubakari A (2018) Salmonella spp. Implication in Products of Wastewater Irrigation. J Trop Dis 6: 283. doi:10.4172/2329-891X. 1000283

Page 5 of 5

15. Gupta SK, Keck J, Ram PK, Crump JA, Miller MA, et al. (2007) Analysis of data gaps pertaining to enterotoxigenic Escherichia coli infections in low and medium human development index countries, 1984-2005, Part 3. Epidemiol Infect 136: 721-738.

16. Amoah P, Drechsel P, Abaidoo RC, Ntow WJ (2006) Pesticide and pathogen contamination of vegetables in Ghana's urban markets. Arch Environ Contam Toxicol 50: 1-6.

17. Seidu R, Abubakari A, Amoah ID, Heistad A,Stenstrom TA, et al. (2015) A probabilistic assessment of the contribution of wastewater-irrigated lettuce to E.coli O157:H7 infection risk and disease burden in Kumasi, Ghana. J Water Health 13: 217-229.

18. Wall PG, Morgan D, Lamden K, et al. (1994) A case control study of infection with anepidemic strain of multiresistant Salmonella typhimurium DT104 in England and Wales. Commun Dis Rep CDR Rev 14: R130-135.

19. Gould LH, Walsh KA, Vieira AR, Herman K, Williams IT, et al. (2013) Surveillance for foodborne disease outbreaks United States, 1998-2008. MMWR Surveill Summ 62: 1-34.

20. Anon (2006) Waterborne pathogens kill 10-20 million people per year. World water and Environmental Engineering 6, aquaculture. Part II Pathogen survival, IRCWD Report No. 04/85.

21. Ghana Medical Journal (2005) Editorial commentary on food safety 2.

22. Scharff RL (2010) Health-related costs from foodborne illness in the United States.

23. LeJeune J, Kersting A (2010) Zoonoses: An occupational hazard for livestock workers and a public health concern for rural communities. Agric Safe Health 16: 161-179.

24. Pachepsky Y, Shelton DR, McLain JET, Patel J, Mandrell RE (2011) Irrigation waters as a source of pathogenic microorganisms in produce. A Review Adv Agron 113: 75-141.
25. Gaukler SM, Linz,GM, Sherwood JS, Dyer NW, Bleier WJ, et al. (2009) E. coli, Salmonella, and Mycobacterium avium sub spp. Paratuberculosis in wild European starlings at a Kansas cattle feedlot. Avian Dis 53: 544-551.

26. Cernicchiaro N, Pearl DL, McEwen SA, Harpster L, Homan HJ, et al. (2012) Association of wild bird density and farm management factors with the prevalence of E. coli O157:H7 in dairy herds in Ohio (2007-2009). Zoon Pub Health 59: 320-329.

27. Amoah P, Drechsel P, Abaidoo RC, Henseler M (2007) Irrigated urban vegetable production in Ghana: Microbiological contamination in farms and markets and associated consumer risk groups. J Water Health 5: 455-466.

28. Drechsel P, Graefe S, Sonou M, Cofie O (2006) Informal irrigation in urban West Africa: An overview, Research Report 102, International Water Management Institute, Colombo, Sri Lanka drinking water. Risk Analysis 13: 545-552.

29. Seidu R Drechsel P (2010) Cost-Effectiveness analysis of treatment and non-treatment interventions for Diarrhoea disease reduction associated with wastewater irrigation. In Pay Drechsel et al. (Ed). Wastewater irrigation and health: assessing and mitigating risk in low-income countries. Earthscan, London.

30. Oliveira M, Vinas I, Usall J, Anguera M, Abadias M (2012) Presence and survival of E. coli O157:H7 on lettuce leaves and in soil treated with contaminated compost and irrigation water. Int J Food Microbiol 156: 133-140.

31. Karesh WB, Dobson A, Lloyd-Smith JO, Lubroth J, Dixon MA, et al. (2012) Ecology of zoonoses: Natural and unnatural histories. Lancet 380: 1936-1945. 